\title{
Pemanfaatan Media Card Short Ayat dalam Meningkatkan Motivasi dan Hasil Pembelajaran Al-Qur'an di Mi Nurul Huda Kota Bengkulu
}

\author{
A. Suradi \\ Prodi PAI Fakultas Tarbiyah dan Tadris IAIN Bengkulu \\ suradi@iainbengkulu.ac.id
}

\begin{abstract}
ABSTRAK
Penelitian ini bertujuan untuk mendeskripsikan pemanfaatan media Card Short ayat dalam meningkatkan motivasi belajar dan meningkatkan hasil belajar siswa dalam pembelajaran Al-Qur'an di MI Nurul Huda Kota Bengkulu. Penelitian ini merupakan Penelitian Tindakan Kelas (Classroom Action Research), yaitu penelitian yang dilakukan di kelas dengan menekankan pada penyempurnaan atau peningkatan proses dan praktis pembelajaran. Berdasarkan hasil penelitian tindakan kelas dapat disimpulkan: (1) Setelah menggunakan media pembelajaran card sort capaian motivasi belajar AlQur'an siswa MI Nurul Huda Kota Bengkulu telah menunjukkan peningkatan. Hal ini bisa dilihat dimana pada siklus I ini mengalami kategori cukup. Kemudian dilanjutkan ke siklus II dan diperoleh hasil kategori baik sesuai dengan apa yang diharapkan. (2) Penggunaan media card sort sangat efektif dalam meningkatkan prestasi belajar Al-Qur'an siswa MI Nurul Huda Kota Bengkulu, hal ini bisa dilihat pada siklus II dan diperoleh hasil hasil belajar dengan nilai rata-rata 80,27 dengan persentase ketuntasan belajar $100 \%$ dengan kategori sangat tinggi dan sudah sesuai dengan apa yang diharapkan.
\end{abstract}

Kata Kunci: Media, Card Short, Motivasi, Hasil Pembelajaran

\section{PENDAHULUAN}

Al-Qur'an adalah kitab Allah yang diturunkan ke dunia yang harus diyakini oleh setiap orang mukmin. Al Qur'an sangat penting bagi manusia, karena tujuan utama diturunkannya kitab suci tersebut menurut Anwar (2009: 1) adalah "untuk menuntun kehidupan manusia ke jalan yang benar yang berujung pada tercapainya kebahagian didunia dan di akhirat". Sealin itu diturunkannya Al Qur'an juga berfungsi sebagai petunjuk bagi seluruh manusia dan sebagai pembeda antara yang hak dan yang batil.

Al Qur'an datang dengan membuka lebarlebar mata munusia, agar mereka menyadari jati diri dan hakikat keberadaan manusia di bumi ini. Allah SWT. memerintahkan kepada manusia untuk beriman kepada Al Qur'an, dan mempelajari serta memahami isi dari Al Qur'an tersebut. Hal ini dinyatakan Allah dalam firmannya "Ini adalah sebuah kitab yang Kami turunkan kepadamu penuh dengan berkah supaya mereka memperhatikan ayat-ayatNya dan supaya mendapat pelajaran orang-orang yang mempunyai fikiran (QS. Shaad/38: 29)."

Dari ayat di atas jelas bahwa sebagai wujud iman kepada Al Qur'an, manusia diperintahkan untuk memperhatikan dan mempelajari Al Qur'an. Di dalam Al Qur'an menurut Shihab (2008: 15) "terdapat petunjuk mengenai apa yang dikehendaki-Nya. Jadi manusia yang ingin menyesuaikan sikap dan perilakunya dengan apa yang dikehendaki dalam Al Qur'an, harus dapat memahami maksud petunjuk-petunjuk tersebut". Upaya tersebut tentu harus didahului dengan mampunya manusia membca Al Qur'an tersebut.

Dengan demikian jelas bahwa beriman kepada al-Qur'an harus dibuktikan dengan mempelajarinya dan mengajarkannya kepada orang lain. Mempelajari al-Qur'an adalah kunci sukses hidup dunia dan akhirat. Dengan mempelajari al-Qur'an maka seseorang akan 
mempunyai banyak pengetahuan yang bermanfaat bagi diri sendiri dan orang lain.

Menurut Syaikh Muhammad bin 'Utsaimin, Al Qur' an secara bahasa (etimologi) merupakan mashdar (kata benda) dari kata kerja Qoro-'a (ترأ) yang bermakna Talaa (تلا) [keduanya berarti: membaca], atau bermakna Jama'a (mengumpulkan, mengoleksi). Anda dapat menuturkan, Qoro-'a Qor'an Wa Qur'aanan (وقرآنا قرءا قرأ) sama seperti anda menuturkan, Ghofaro Ghafran Wa Qhufroonan (وغفرانا غفرا غفر). Berdasarkan makna pertama (Yakni: Talaa) maka ia adalah mashdar (kata benda) yang semakna dengan Ism Maf'uul, artinya Matluw (yang dibaca). Sedangkan berdasarkan makna kedua (Yakni: Jama'a) maka ia adalah mashdar dari Ism Faa'il, artinya Jaami' (Pengumpul, Pengoleksi) karena ia mengumpulkan/mengoleksi berita-berita dan hukum-hukum, (Syaikh Muhammad bin 'Utsaimin http://alilmu. wordpress.com/2017/04/13/ mukhtashar-ulumil-quraan/).

Adapun standar kompetensi dalam membaca ataupun menghafal Al Qur'an di Madrasah Ibtidaiyah dimulai dari Kelas I sampai Kelas VI. Standar kompetensinya meliputi menghafal Al-Qur'an surat pendek pilihan, membaca Al-Qur'an surat pendek pilihan, mengenal kalimat dalam Al-Qur'an, mengenal ayat-ayat Al-Qur'an, membaca suratsurat Al-Qur'an, serta mengartikan Al-Qur'an surat pendek pilihan (Standar Kompetensi dan Kompetensi Dasar Tingkat SD, MI, Dan SDLB).

Mengingat begitu pentingnya materi membaca, mengenal, menghafal ataupun mengartikan Al-Qur'an bagi siswa, maka berbagai upaya haruslah dilakukan guru agar siswa memiliki pengetahuan dan kemampuan dalam membaca, menghafalkan dan mengartikan ayat Al-Qur'an. Upaya guru tersebut tentunya haruslah dibarengi dengan penggunaan pendekatan, metode, sarana dan prasarana pembelajaran dan sebagainya yang sesuai dengan pembelajaran Al-Qur'an.

Selain pendekatan, metode, sarana dan prasarana, yang tidak kalah pentingnya adalah ketersediaan media pembelajaran yang dapat mempermudah dan membantu guru dalam proses pembelajaran. Karena, menurut Usman dan Asnawir (2008: 7) "media pembelajaran dapat dikatakan sebagai salah satu faktor penentu keberhasilan pembelajaran. Melalui media proses pembelajaran bisa lebih menarik dan menyenangkan (joyfull learning)".

Dalam kegiatan sehari hari, penulis mengamati guru terkesan mengabaikan penggunaan media dalam pembelajaran alQur'an. Berbagai alasan dikemukakan guru mulai dari keterbatasan waktu, terlalu luasnya materi, tidak adanya keinginan belajar siswa dan berbagai alasan lainnya. Khusus dalam materi Al Qur'an yang terjadi adalah rendahnya kemampuan siswa dalam membaca, menghafal ataupun mengartikan Al Qur'an, serta banyaknya ditemukan kesalahan siswa dalam membaca Al Qur'an.

Kondisi ini masih banyaknya model pembelajaran yang dikembangkan guru dalam menyampaikan materi Al Qur'an yang sepenuhnya bermazhab pada konsep "transfer of knowledge". Artinya, pembelajaran $\mathrm{Al}$ Qur'an hanya dilakukan dengan menggunakan cara-cara lama seperti dengan ceramah atau dengan memanggil siswa satu persatu untuk membaca atau menghafal Al-Qur'an.

Dengan metode ceramah dan pendekatan yang dilakukan guru tersebut dalam kenyataannya belum dapat meningkatkan pengetahuan siswa dalam membaca atau menghafal Al-Qur'an, dan ini bermuara kepada tidak tercapainya kompetensi dasar yang harus dikuasai siswa. Hal ini terbukti dari masih banyaknya siswa yang belum dapat membaca Al Qur'an dengan tartil dan benar, kesulitan dalam menghafal serta menulisnya.

Melihat kondisi di atas, maka guru MI Nurul Huda Kota Bengkulu berusaha untuk mengembangkan pembelajaran Al-Qur'an ini melalui penggunaan Short Card Ayat Al-Qur'an. Short Card Ayat merupakan alat bantu pembelajaran dengan bantuan potonganpotongan ayat untuk mengajarkan cara membaca Al-Qur'an. Oleh sebab itu, penulis tertarik melakukan penelitian dengan judul "Pemanfaatan media card short ayat dalam meningkatkan motivasi dan hasil belajar siswa pada pembelajaran Al-Qur'an di MI Nurul Huda Kota Bengkulu".

\section{METODE PENELITIAN}

Penelitian ini merupakan Penelitian Tindakan Kelas (Classroom Action Research), yaitu penelitian yang dilakukan di kelas dengan menekankan pada penyempurnaan atau 
peningkatan proses dan praktis pembelajaran, (Arikunto, 2010: 96). Peneliti melaksanakan 2 (dua) siklus yang masing-masing siklus terdiri dari 5 tahap, yaitu: perencanaan (planning), tindakan (acting), pengamatan (observation), evaluasi (evaluation) dan refleksi (reflection).

Dari beberapa uraian di atas, penelitian tindakan kelas diawali dengan perencanaan, penerapan tindakan, mengobservasi dan mengevaluasi proses serta hasil tindakan, lalu melakukan refleksi, dan seterusnya sampai perbaikan atau peningkatan yang diharapkan tercapai.

\section{Subjek Penelitian}

Subjek penelitian merupakan seseorang yang berpartisipasi dan yang memberikan laporan mengenai pengalamannya yang dibutukan dalam penelitian. Adapun yang menjadi subjek dalam penelitian ini adalah guru Al-Qur'an Hadis di MI Nurul Huda Kota Bengkulu yang berjumlah 1 orang dan siswa kelas IIIB sebanyak 24 orang.

\section{Rancangan Penelitian}

Penelitian ini merupakan tergolong penelitian lapangan dengan jenis penelitian tindakan kelas (PTK). Pada penelitian ini, peneliti merencanakan 2 siklus yang masingmasing siklus terdiri dari 5 tahap, yaitu sebagai berikut:

a. Perencanaan (planning), yakni menyusun rancangan tindakan dan perencanaan yang akan dilaksanakan dalam penelitian tindakan.

b. Tindakan (action), yakni penerapan isi rancangan sesuai dengan rencana tindakan.

c. Pengamatan (observation) yakni pelaksanaan pengamatan selama proses penerapan berlangsung.

d. Evaluasi/tes (evalution) yakni mengevaluasi atau menilai setiap akhir siklus.

e. Refleksi (reflection), yakni kegiatan untuk mengemukakan kembali apa yang telah terjadi selama dalam pelaksanaan penelitian tindakan kelas.

Dalam penelitian ini, penulis menggunakan teknik pengumpulan data sebagai berikut:

\section{Observasi}

Observasi dilakukan dengan mengamati langsung kondisi kegiatan belajar mengajar. Metode ini merupakan suatu teknik pengumpulan data yang terlibat langsung mengamati tentang kondisi dan aktivitas dalam penggunaan media Card Short ayat guna mengetahui motivasi siswa belajar pada Mata Pelajaran Al-Qur'an Hadis di Kelas III MI Nurul Huda Kota Bengkulu.

2. Tes

Teknik yang digunakan untuk mengetahui peningkatan hasil belajar pada mata pelajaran Al-Qur'an Hadis yang dilakukan siswa setiap siklusnya adalah berupa tes prestasi/ajek tes. Tes diberikan kepada siswa pada setiap siklus di akhir pembelajaran. Soal tes ini diambil dari buku Mata Pelajaran AlQur'an Hadis yang relevan.

3. Dokumentasi

Teknik dokumentasi ini penulis gunakan untuk melengkapi observasi dan tes. Dokumentasi yang dimaksud di sini adalah catatan-catatan dan tulisan-tulisan yang berisi tentang jumlah siswa, guru dan karyawan, sarana dan prasarana yang dimiliki oleh MI Nurul Huda Kota Bengkulu.

Untuk mengetahui penggunaan media Card Short ayat meningkatkan motivasi dan hasil belajar siswa pada Mata Pelajaran AlQur'an Hadis, penulis menggunakan teknik analisis kuantitatif, yakni menggambarkan hasil penelitian yang diperoleh langsung dari lapangan dengan menggunakan angka. Analisis ini dihitung dengan statistik sederhana, yakni peneliti menjumlahkan nilai yang diperoleh siswa, dibagi dengan jumlah siswa tersebut sehingga memperoleh nilai rata-rata (mean), (Aqib, 2010: 40).

Rumus mencari nilai rata-rata (mean):

$$
\mathrm{M}=\frac{\sum \mathrm{X}}{\sum \mathrm{N}}
$$

Keterangan:

$\mathrm{M}=$ nilai rata-rata

$\sum \mathrm{X} \quad=$ jumlah semua nilai siswa

$\sum \mathrm{N}=$ jumlah siswa

Untuk menghitung persentase ketuntasan belajar digunakan rumus sebagai berikut:

$\mathrm{P}=\sum$ siswa yang tuntas belajar $\times 100 \%$ $\sum$ siswa

Adapun tabel kriteria keberhasilan siswa 
Tabel kriteria tingkat keberhasilan belajar siswa dalam \%

\begin{tabular}{|c|c|}
\hline $\begin{array}{c}\text { Tingkat } \\
\text { keberhasilan }(\%)\end{array}$ & Arti \\
\hline$>80 \%$ & Sangat tinggi \\
\hline $60-79 \%$ & Tinggi \\
\hline $40-59 \%$ & Sedang \\
\hline $20-39 \%$ & Rendah \\
\hline$<20 \%$ & Sangat rendah \\
\hline
\end{tabular}

\section{HASIL PENELITIAN}

\section{A. Hasil Siklus I}

Siklus I dilaksanakan dengan tiga kali pertemuan. Data hasil yang diperoleh telah peneliti tampilkan pada siklus I, dari hasil analisis data siklus I peneliti menghitung jumlah skor dan nilai rata-rata dari lembar observasi dan lembar hasil belajar siswa, dari data yang didapat maka pada siklus I didapat 108 skor dengan rata-rata 3,6 untuk kemampuan dalam menggunakan media card sort maka dapat disimpulkan kemampuan guru dalam melaksanakan tindakan tergolong cukup. Sedangkan untuk motivasi siswa didapat 103 skor dengan niali rata-rata 3,43 , maka motivasi siswa dalam proses pembelajaran masih tergolong cukup.

Tes hasil belajar siswa dihitung dengan menggunakan rumus persentase ketuntasan belajar, dari data yang peniliti hitung maka hasil belajar siswa pada mata pelajaran AlQur'an Hadis pada siklus I didapat 79,16\% siswa yang dinyatakan tuntas dengan nilai ratarata 70,45 hal ini menandakan bahwa hasil belajar siswa masih cukup dan dianggap masih perlu untuk diadakan tindakan lanjut ke siklus II.

\section{B. Hasil Penelitian Siklus II}

Pada siklus ini peneliti melakukan perbaikan-perbaikan pada indikator-indikator yang masih kurang pada siklus I. Dari hasil analisis data siklus II peneliti menghitung jumlah skor dari observasi dan tes hasil belajar siswa. Pada siklus II didapat skor 122 dengan nilai rata-rata 4,07 untuk kemampuan guru dalam menggunakan media card sort . Dari skor tersebut maka dapat disimpulkan bahwa kemampuan guru dalam melaksanakan tindakan sudah tergolong baik. Sedangkan untuk motivasi siswa didapat 121 skor dengan nilai rata-rata 4,03 maka motivasi siswa pada proses pembelajaran pada siklus ini sudah tergolong baik.

Tes hasil belajar siswa dihitung dengan menggunakan rumus persentase ketuntasan belajar. Dari data yang peneliti hitung maka hasil belajar pada mata pelajaran Al-Qur'an Hadis di kelas III B MI Nurul Huda Kota Bengkulu pada siklus II didapat $100 \%$ siswa yang dinyatakan tuntas dengan nilai rata-rata 80,27, hal ini menandakan bahwa tindakan yang telah dilakukan sudah sesuai dengan perencanaan yang disusun sebelum dan setelah mencapai hasil belajar yang diharapkan atas hasil yang dicapai pada siklus II maka tidak perlu diadakan tindakan pada siklus selanjutnya.

\section{Pembahasan Semua Siklus}

Hasil yang diperoleh oleh peneliti selama penelitian berlangsung dapat dilihat pada tabel dibawah ini :

Tabel. 1

Hasil Observasi Aktivitas Guru Pada Siklus I dan II

\begin{tabular}{ccccc}
\hline No & Siklus & Skor & $\begin{array}{c}\text { Rata- } \\
\text { rata }\end{array}$ & Kategori \\
\hline 1 & I & 108 & 3,6 & Cukup \\
\hline 2 & II & 122 & 4,07 & Baik \\
\hline
\end{tabular}

Tabel. 2

Hasil Observasi Motivasi Siswa Pada Siklus I dan II

\begin{tabular}{ccccc}
\hline No & Siklus & Skor & $\begin{array}{c}\text { Rata- } \\
\text { rata }\end{array}$ & Kategori \\
\hline 1 & I & 103 & 3,43 & Cukup \\
\hline 2 & II & 121 & 4,03 & Baik \\
\hline
\end{tabular}

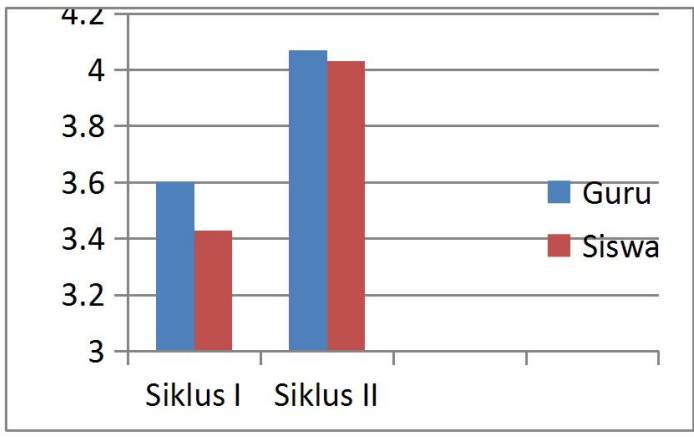

Gambar 1. Hasil Observasi Guru dan Siswa Pada Siklus I dan Siklus II

Dari tabel dan grafik tersebut dapat dilihat peningkatan hasil rata- rata lembar observasi guru dan lembar observasi siswa pada siklus I dan siklus II. Nilai rata-rata lembar 
observasi guru pada siklus I adalah 3,3 kategori cukup dan terjadi peningkatan pada siklus II adalah 4,00 dan tergolong dalam kategori baik. Sedangkan nilai rata-rata lembar observasi siswa siklus I adalah 3,0 tergolong kedalam kategori cukup dan terjadi peningkatan nilai rata-rata pada siklus II yaitu 4,00 tergolong dalam kategori baik.

Pada pelaksanaan tindakan dengan menggunakan media card sort pada siklus II ini telah berjalan dengan baik. Karena proses belajar mengajar sudah berjalan sangat baik dengan menggunakan media card sort dan hasil belajar sudah mencapai target yaitu 100\% dari jumlah siswa. Sehingga tidak perlu melakukan tindakan kelas pada siklus selanjutnya.
Adapun keberhasilan yang diperoleh pada pembelajaran di siklus II ini adalah sebagai berikut :

a. Aktifitas guru dan motivasi siswa dalam proses belajar mengajar sudah mengarah pada pembelajaran yang baik, dan telah mengalami peningkatan dari siklus I ke siklus II.

b. Hasil belajar siswa telah mengalami peningkatan dari pra siklus, siklus I dan siklus II.

Setelah diketahui hasil belajar sudah mencapai target yang diinginkan dan aspekaspek yang belum terlaksana pada siklus I sudah tuntas maka peneliti menghentikan penelitian tindakan kelas pada siklsus II ini.

Tabel 3. Capaian Hasil Belajar Pra Siklus, Siklus I dan Siklus II

\begin{tabular}{|c|c|c|c|c|c|}
\hline No & Nama & KKM & Pra Siklus & Siklus I & Siklus II \\
\hline 1 & Ahmad Rosyidin & 60 & 70 & 70 & 90 \\
\hline 2 & Arlinda Hayati & 60 & 50 & 56,7 & 80 \\
\hline 3 & Dea Ayu Lestari & 60 & 80 & 80 & 80 \\
\hline 4 & Della Fatika & 60 & 80 & 81,7 & 85 \\
\hline 5 & Elda Jumiarti & 60 & 50 & 75 & 81,7 \\
\hline 6 & Erlan Dwi Guna & 60 & 50 & 56,7 & 80 \\
\hline 7 & Harisma Fajri Ardi & 60 & 50 & 80 & 80 \\
\hline 8 & Metrolianto & 60 & 50 & 85 & 85 \\
\hline 9 & Mugiono & 60 & 50 & 60 & 80 \\
\hline 10 & Pepi Septa Haroja & 60 & 50 & 75 & 80 \\
\hline 11 & Roni Apriansyah & 60 & 50 & 56,7 & 80 \\
\hline 12 & Randika Adi & 60 & 70 & 70,7 & 80 \\
\hline 13 & Ridho Bagus Prasetyo & 60 & 40 & 58,3 & 63,3 \\
\hline 14 & Sita Azahra Wulan & 60 & 80 & 76,7 & 83,3 \\
\hline 15 & Taufik Nur Rahman & 60 & 70 & 75 & 83,3 \\
\hline 16 & Kamaludin & 60 & 60 & 55 & 83,3 \\
\hline 17 & Siti Rohimah & 60 & 70 & 68,3 & 75 \\
\hline 18 & Juliansyah & 60 & 50 & 76,7 & 80 \\
\hline 19 & Hairani Disti & 60 & 50 & 76,7 & 80 \\
\hline 20 & Raudhatul Aini & 60 & 60 & 68,3 & 80 \\
\hline 21 & Ramdhani & 60 & 50 & 76,7 & 80 \\
\hline 22 & Ahmad Jayadi & 60 & 70 & 66,7 & 76,7 \\
\hline 23 & Waladun Jayid & 60 & 50 & 71,7 & 80 \\
\hline 24 & Sujarmi & 60 & 50 & 73,3 & 80 \\
\hline
\end{tabular}

Selain di atas, berikut nilai hasil belajar kelas kontrol yang diambil dari hasil tes pada materi yang sama, yakni kelas IIIC MI Nurul huda Kota Bengkulu sebagai berikut: 
Tabel 4. Capaian Hasil Belajar Sebagai Kelas Kontrol Kelas IIIC

\begin{tabular}{|c|l|c|c|c|c|}
\hline \multirow{2}{*}{ No } & \multirow{2}{*}{ NKama } & \multicolumn{2}{|c|}{ Pertemuan } & \multirow{2}{*}{ Keterangan } \\
\cline { 4 - 5 } & & & I & II & \\
\hline 1 & Tajuddin & 60 & 60 & 70 & Tuntas \\
\hline 2 & Revano Alfando & 60 & 50 & 50 & Tdk tuntas \\
\hline 3 & Dian Kusuma Putri & 60 & 70 & 70 & Tuntas \\
\hline 4 & Mahdalena & 60 & 70 & 70 & Tuntas \\
\hline 5 & Nif'an nazudi & 60 & 60 & 70 & Tuntas \\
\hline 6 & Risnawati & 60 & 50 & 50 & Tdk tuntas \\
\hline 7 & Maimunah Hesti & 60 & 50 & 70 & Tuntas \\
\hline 8 & Ahmad Ramdani & 60 & 50 & 50 & Tdk tuntas \\
\hline 9 & Jamaluddin & 60 & 50 & 50 & Tdk tuntas \\
\hline 10 & Hartati & 60 & 60 & 70 & Tuntas \\
\hline 11 & Reflan Haiti & 60 & 50 & 50 & Tdk tuntas \\
\hline 12 & Suhania & 60 & 70 & 70 & Tuntas \\
\hline 13 & Sutikno & 60 & 50 & 60 & Tuntas \\
\hline 14 & Rita Zahara & 60 & 70 & 70 & Tuntas \\
\hline 15 & Diana Galbin & 60 & 70 & 80 & Tuntas \\
\hline 16 & Khairul Anwar & 60 & 60 & 60 & Tuntas \\
\hline 17 & Riftan Jati & 60 & 60 & 60 & Tuntas \\
\hline 18 & Solahul Najah & 60 & 50 & 50 & Tdk tuntas \\
\hline 19 & Mahatun Shalihah & 60 & 50 & 70 & Tuntas \\
\hline 20 & Fidyatul Afkar & 60 & 60 & 60 & Tuntas \\
\hline 21 & Junainah & 60 & 50 & 50 & Tdk tuntas \\
\hline 22 & Mahmudi & 60 & 70 & 60 & Tuntas \\
\hline 23 & Jamratul Maidah & 60 & 60 & 60 & Tuntas \\
\hline & Jumlah Nilai (I-II) & & & $\mathbf{2 7 6}$ & \\
\hline & Nilai Rata-Rata (I-II) & & \multicolumn{2}{|c}{} & \\
\hline
\end{tabular}

Dari hasil belajar siswa pada kelas kontrol (kelas IIIC), nilai rata-rata yaitu 60 . Dengan nilai terendah 50 dan nilai tertinggi 80 . Diantaranya 7 siswa yang mendapatkan nilai dibawah 60 dan 16 orang siswa yang mendapatkan nilai diatas 60 . Jika dihitung berdasarkan persentase ketuntasan belajar maka sudah $69,56 \%$ siswa yang tuntas.

Untuk lebih jelasnya, persentase ketuntasan belajar siklus II dilihat pada tabel dibawah ini :

\section{Tabel 5}

Persentase ketuntasan hasil belajar

No Nilai KKI Jumlah Persentase Katagori Siswa ketuntasan ketuntasan

1 Diata $16 \quad 69,56 \quad$ Tuntas
s 60 $\%$

\section{Persentase Hasil Belajar Pra Siklus, Siklus I dan Siklus II}

Hasil yang diperoleh oleh peneliti selama penelitian tindakan berlangsung pada pra siklus, siklus I dan siklus II dapat dilihat pada tabel di bawah ini :
Tabel 6

Persentase Hasil Belajar Al-Qur'an Hadis pra siklus, siklus I dan siklus II

\begin{tabular}{|c|c|c|c|c|}
\hline No & Siklus & $\begin{array}{c}\text { Nilai } \\
\text { rata- } \\
\text { rata }\end{array}$ & $\begin{array}{c}\text { Persentase } \\
\text { ketuntasa } \\
\text { n belajar }\end{array}$ & Keterangan \\
\hline 1 & Pra & $\begin{array}{c}58,3 \\
3\end{array}$ & $37,5 \%$ & Sedang \\
\hline 2 & I & $\begin{array}{c}70,4 \\
5\end{array}$ & $\begin{array}{c}79,16 \\
\%\end{array}$ & Tinggi \\
\hline 3 & II & $\begin{array}{c}80,2 \\
7\end{array}$ & $100 \%$ & $\begin{array}{l}\text { Sangat } \\
\text { Tinggi }\end{array}$ \\
\hline
\end{tabular}

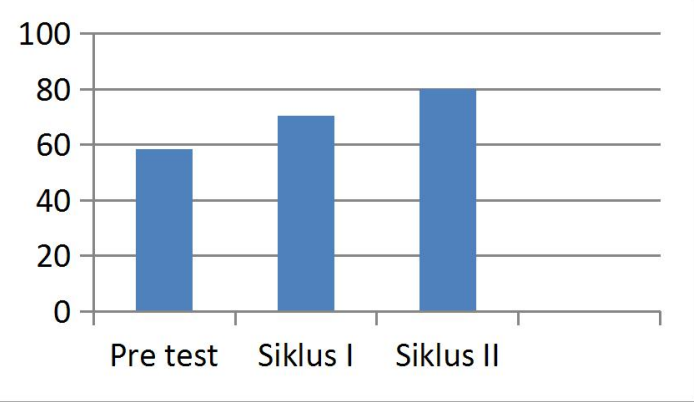

Gambar 2. Nilai Rata-Rata

Dari tabel dan grafik di atas dapat dilihat pertimbangan jumlah nilai rata-rata dan A.Suradi. Pemanfaatan Media Card Short Ayat dalam Meningkatkan Motivasi dan ..., halaman 146-152 
persentase ketuntasan belajar dari pra siklus, siklus I dan siklus II. Nilai rata-rata sebelum siklus 58,33 dengan persentase $37,5 \%$ dan terjadi peningkatan pada siklus I yaitu 70,45 dengan persentase $79,16 \%$ namun masih dibawah standar dan kemudian dilanjutkan pada siklus II dengan nilai rata-rata 80,27 dengan persentase $100 \%$ dan dapat dinyatakan bahwa tindakan yang dilakukan sudah sesuai dengan apa yang diharapkan.

Dengan demikian peneliti menyimpulkan bahwa penggunaan media card sort dalam meningkatkan hasil belajar AlQur'an Hadis telah berhasil, hal ini terbukti dengan hasil akhir hasil belajar yang diperoleh peserta didik meningkat. Penggunaan media card sort ini sejalan dengan teori dimana gerakan fisik yang dominan pada media pembelajaran ini dapat membantu mendinamiskan kelas yang jenuh dan bosan, dimana media card sort merupakan suatu strategi yang digunakan pendidik dengan maksud mengajak peserta didik untuk menemukan dan mengajarkan konsep, karakter, klasifikasi, dan fakta tentang objek materi yang dibahas dalam pembelajaran.

\section{KESIMPULAN}

Berdasarkan hasil penelitian tindakan kelas tentang penerapan media Card Short ayat dalam meningkatkan motivasi dan hasil belajar siswa pada mata pelajaran Al-Qur'an di MI Nurul Huda Kota Bengkulu dapat disimpulkan adalah: Pertama, Setelah menggunakan media pembelajaran card sort capaian motivasi belajar Al-Qur'an siswa MI Nurul Huda Kota Bengkulu telah menunjukkan peningkatan. Hal ini bisa dilihat dimana pada siklus I ini mengalami kategori cukup. Kemudian dilanjutkan ke siklus II dan diperoleh hasil kategori baik sesuai dengan apa yang diharapkan.

Kedua, Penggunaan media card sort sangat efektif dalam meningkatkan hasil belajar Al-Qur'an siswa MI Nurul Huda Kota Bengkulu, hal ini bisa dilihat dimana pada kemampuan awal sebelum dilakukan tindakan (Pra siklus) diperoleh hasil hasil belajar siswa dengan nilai rata-rata 58,33 dengan persentase ketuntasan belajar $37,5 \%$ dengan kategori sedang. Untuk itu kemudian peneliti melaksanakan siklus I, pada siklus I ini terjadi peningkatan yaitu diperoleh hasil hasil belajar dengan nilai rata-rata siswa 70,45 dan persentase ketuntasan belajar 79,16\% demngan kategori tinggi tapi belum mencapai target yang diinginkan. Oleh karena itu penelitian dilanjutkan ke siklus II dan diperoleh hasil hasil belajar dengan nilai rata-rata 80,27 dengan persentase ketuntasan belajar $100 \%$ dengan kategori sangat tinggi dan sudah sesuai dengan apa yang diharapkan.

\section{DAFTAR PUSTAKA}

Anwar, Abu. 2009. Ulumul Qur'an Sebuah Pengantar. Jakarta : Penerbit Amzah.

Aqib, Zainal. 2010. Penelitian Tindakan Kelas (PTK). Bandung: Yrama Widya.

Arikunto, Suharsimi. 2010. Prosedur Penelitian, Suatu Pendekatan Praktis. Jakarta: Rineka Cipta.

Arsyad, Azhar. 2010. Media Pembelajaran. Jakarta : PT. Raja Grafindo Persada.

Departemen Agama RI, 2007. Al-Qur'an dan Terjemahnya, (Jakarta)

Ismail, Abdul Mujib dan Maria Ulfah Nawawi. 2005. Pedoman Ilmu Tajwid. Surabaya : Penerbit Karya Abditama.

Peraturan Pemerintah Nomor 19 Tahun 2005 tentang Standar Nasional Pendidikan

Permendiknas No. 22 Tahun 2006 tentang Standar Kompetensi dan Kompetensi Dasar Tingkat SD, MI, Dan SDLB.

Sadiman, Arif S. dkk. 2010. Media Pendidikan, Pengertian, Pengem-bangan dan Pemanfaatannya. Jakarta: Rajawali Pers.

Sardiman, AM. 2010. Interaksi dan Motivasi Belajar Mengajar. Jakarta: PT. Raja Grafindo Persada.

Shihab, Quraish. 2008. Membumikan Al-Qur'an: Fungsi dan Peran Wahyu dalam Kehidupan Masyarakat. Bandung: Penerbit Mizan.

Syaikh Muhammad bin 'Utsaimin sebagaimana dikutip Aufa dalam http://alilmu.wordpress.com/2007/04/13/ mukhtashar-ulumil-quraan/. Diaksess tanggal 15 September 2017.

Usman, Basyarudin dan Asnawir. 2008. Media Pembelajaran. Jakarta: Delia Citra Utama.

Zaini, Hizam. 2010. Model Pembelajaran Inovatif, Jakarta. 